\title{
Endoscopic submucosal dissection of a gastric neoplasm with osseous metaplasia
}

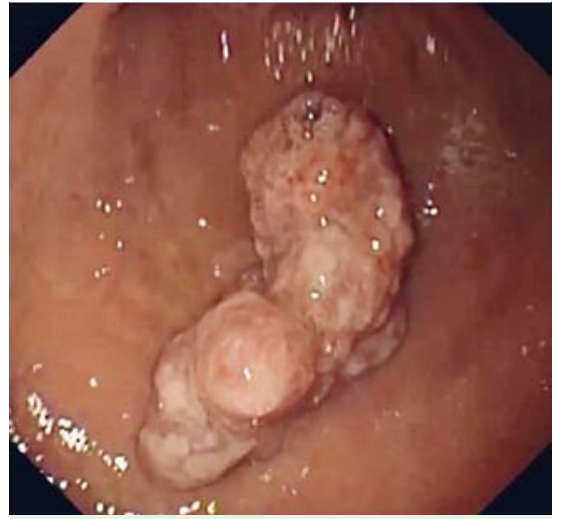

Fig. 1 Endoscopic view showing the gastric lesion, which was type 0 -Ila + Is (Paris Classification), $60 \mathrm{~mm}$ in largest diameter, and located in the greater curvature of the distal gastric body.

Heterotopic ossification is a phenomenon that is described in a variety of tissue types, in both neoplastic and non-neoplastic conditions, although it is more often seen in degenerative diseases. In the gastrointestinal (GI) tract, osseous metaplasia is less common but it can occur in carcinomas and some benign neoplasms [1].

We report the case of a 66-year-old previously healthy and asymptomatic woman who was referred to our endoscopy unit for endoscopic submucosal dissection (ESD) of an unusual gastric lesion, a type 0-IIa+Is (Paris Classification) lesion of $60 \mathrm{~mm}$ in largest diameter, which was located in the greater curvature of the distal gastric body ( $\nabla$ Fig. 1). The lesion had been diagnosed by an upper GI endoscopy done in the context of gastric cancer screening. The patient was submitted to ESD ( Video 1), thereby allowing en bloc resection to be performed.

Histological examination of the lesion showed cyto-architectural features of a hyperplastic and adenomatous polyp with high grade dysplasia and with multiple foci of well-differentiated tubular adenocarcinoma with invasion of the muscularis mucosa ( $\bullet$ Fig.2a). Bone metaplasia was also found in some areas of the lesion ( Fig. $\mathbf{2 b}$ ). Examination of the specimen confirmed an $\mathrm{R} 0$ resection and the patient continues to be followed up with no signs of disease recurrence.

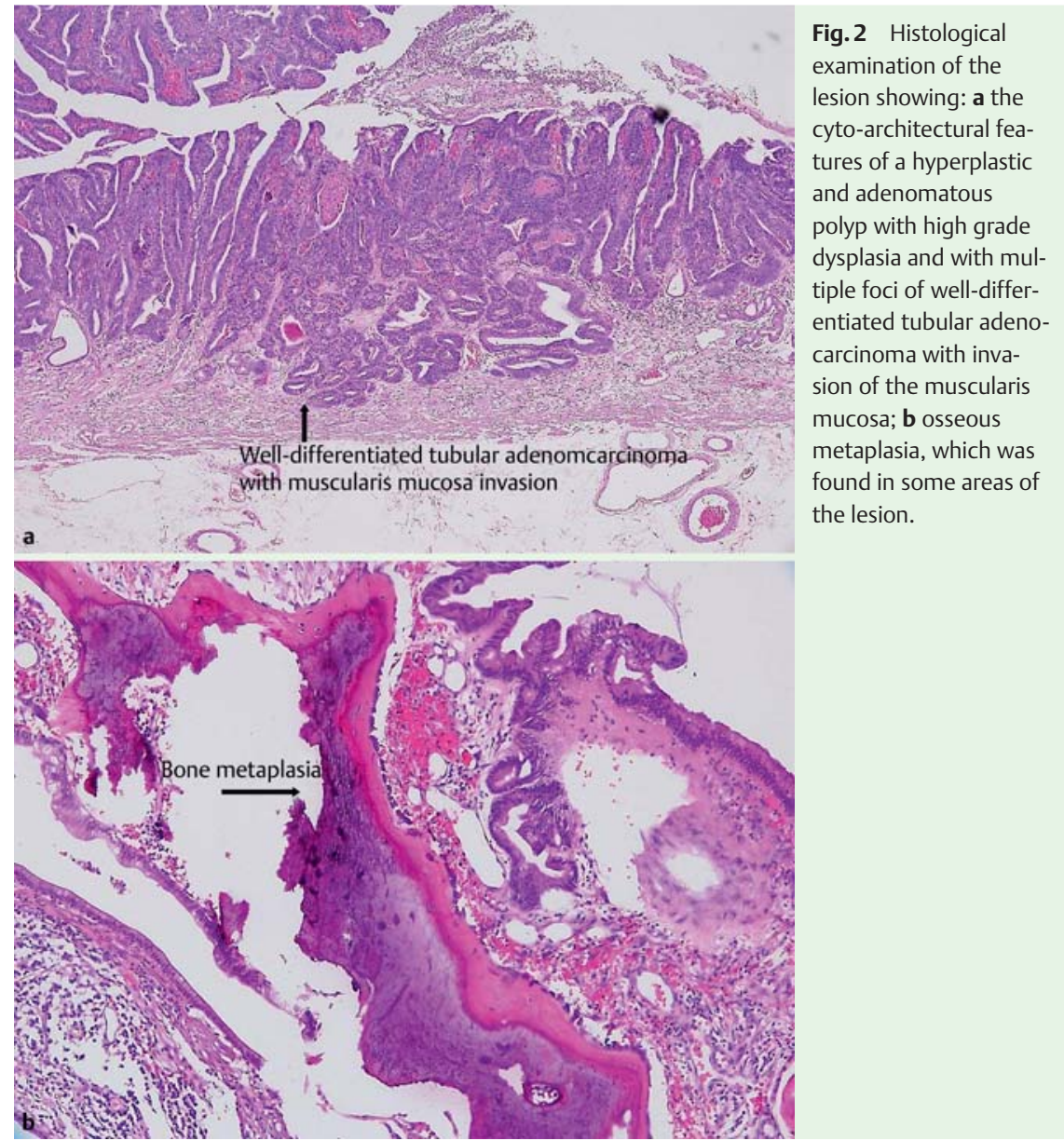

Osseous metaplasia is very rare in the stomach and only a few reported cases have been published. Ohtsuki et al. reported bone metaplasia in a gastric hyperplastic polyp [2], Zapata et al. reported it in a gastric adenomatous polyp [3], and Olinici et al. reported it in a gastric carcinoma [4]. The exact mechanism of bone formation in gastric neoplasms has yet to be elucidated, but it may result from the ability of pluripotent stromal cells, such as fibroblasts, to transform into osteoblasts, rather than osseous metaplasia occurring in tumor cells.

In conclusion, we present the treatment of a very rare gastric neoplasm with a striking morphological feature, namely heterotopic ossification. The prognostic meaning of this remains unclear but so far it seems to have had no clinical significance.

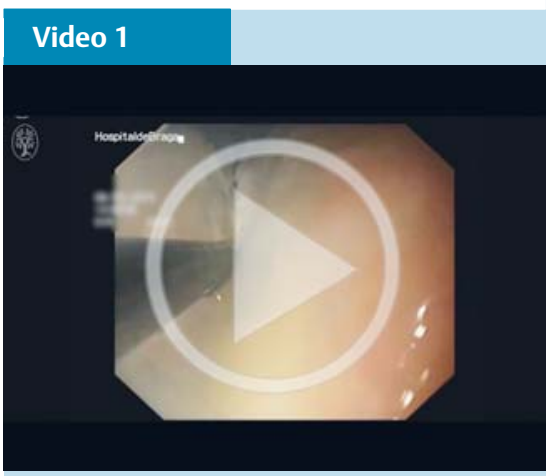

Endoscopic submucosal dissection (ESD) of a very rare case of a gastric neoplasm with heterotopic ossification.

Endoscopy_UCTN_Code_CCL_1AB_2AD_3AB

Competing interests: None 
Rita Seara Costa ${ }^{1}$, Sofia Carvalho², Ana Isabel Silva ${ }^{2}$, Aníbal Ferreira ${ }^{1}$

${ }^{1}$ Department of Gastroenterology, Hospital of Braga, Portugal

2 Department of Pathology, Hospital of Braga, Portugal

\section{References}

1 Liu K, Tripp S, Layfield LJ. Heterotopic ossification: review of histologic findings and tissue distribution in a 10-year experience. Pathol Res Pract 2007; 203: 633-640

2 Ohtsuki Y, Danbara Y, Takeda I et al. Metaplastic bone formation in a hyperplastic polyp of the stomach: a case report. Acta Med Okayama 1987; 41: 43-46

3 Zapata E, Castiella A, Zubiaurre L et al. Osseous metaplasia in a gastric adenomatous polyp. Endoscopy 2012; 44 (Suppl. 02): E81

4 Olinici CD, Domşa I, Drăghici A et al. Heterotopic bone formation in gastric carcinoma. Case report and discussion of the literature. Rom J Gastroenterol 2002; 11: 331 - 333

\section{Bibliography}

Dol http://dx.doi.org/ 10.1055/s-0042-115939 Endoscopy 2016; 48: E309-E310 (c) Georg Thieme Verlag KG Stuttgart · New York ISSN 0013-726X

\section{Corresponding author}

Rita Seara Costa, MD

Department of Gastroenterology Hospital of Braga

Sete Fontes - São Victor

4710-243 Braga

Portugal

rita.seara.costa@gmail.com 